\title{
The cost of toxin production in phytoplankton: the case of PST producing dinoflagellates
}

\author{
Subhendu Chakraborty ${ }^{1}$ Marina Pančić ${ }^{1}$ Ken H. Andersen $\mathbb{I}^{1} \cdot$ Thomas Kiørboe $^{1}$
}

Received: 25 April 2018 / Revised: 29 June 2018 / Accepted: 19 July 2018 / Published online: 14 August 2018

(c) International Society for Microbial Ecology 2018

\begin{abstract}
Many species of phytoplankton produce toxins that may provide protection from grazing. In that case one would expect toxin production to be costly; else all species would evolve toxicity. However, experiments have consistently failed to show any costs. Here, we show that costs of toxin production are environment dependent but can be high. We develop a fitness optimization model to estimate rate, costs, and benefits of toxin production, using PST (paralytic shellfish toxin) producing dinoflagellates as an example. Costs include energy and material (nitrogen) costs estimated from well-established biochemistry of PSTs, and benefits are estimated from relationship between toxin content and grazing mortality. The model reproduces all known features of PST production: inducibility in the presence of grazer cues, low toxicity of nitrogen-starved cells, but high toxicity of P-limited and light-limited cells. The model predicts negligible reduction in cell division rate in nitrogen replete cells, consistent with observations, but $>20 \%$ reduction when nitrogen is limiting and abundance of grazers high. Such situation is characteristic of coastal and oceanic waters during summer when blooms of toxic algae typically develop. The investment in defense is warranted, since the net growth rate is always higher in defended than in undefended cells.
\end{abstract}

\section{Introduction}

Many phytoplankton species produce substances that are toxic to humans, hence we consider such phytoplankton 'toxic algae', but the evolution and functional role of these secondary metabolites remain unclear. They may be released into the environment and have allelochemical effects to combat competitors [1,2] or grazers [3], they may be mainly intracellular and have toxic and/or deterrent effects on grazers [4, 5], or in mixotrophic species that they may have offensive roles, functioning as a venom towards prey [6-8]. Some toxic algae may also form dense blooms, potentially promoted by their toxicity and consequent grazer deterrent effects, and a defensive role of toxin production is

Electronic supplementary material The online version of this article (https://doi.org/10.1038/s41396-018-0250-6) contains supplementary material, which is available to authorized users.

Subhendu Chakraborty

subc@aqua.dtu.dk

1 Centre for Ocean Life, DTU Aqua, Technical University of Denmark, Kemitorvet, Kgs.2800, Lyngby, Denmark thus often assumed [4, 9]. This interpretation is supported by the observations that algal toxins often have a deterrent rather than a toxic effect on grazers [10-15], and that toxin production may be upregulated in the presence of grazers or their cues, as demonstrated in dinoflagellates, Alexandrium spp. [13, 16, 17], and in diatoms, Pseudo-nitzschia spp. [18]. The latter observation also suggests that toxin production comes at a cost-why else regulate the production in response to the need? Optimal defense theory, well founded in terrestrial plant ecology, predicts that inducibility of defense should evolve only when the defense is costly and variable in time [19]. However, experiments have generally been unable to demonstrate such costs in toxic phytoplankton, and the growth rates of grazer-induced and un-induced cells, or of toxic and nontoxic strains of the same phytoplankton species appear to be similar [3, 13, 16, 18], and model exercises have similarly suggested costs to be trivial [20]. However, if defense via toxin production is both effective and costless, one would expect most phytoplankton to be toxic, which is far from being the case [19]. Also, the promotion of phytoplankton diversity in the ocean due to grazing and consequent evolution of defense mechanisms, as demonstrated in both theoretical models and considerations [21-23] and whole-community 
Table 1 Central symbols and general parameters

\begin{tabular}{|c|c|c|c|c|}
\hline Symbol & Description & Value & Unit & Reference \\
\hline $\mathrm{L}$ & Light flux in the environment & - & $\mu \mathrm{E} \mathrm{m}^{-2} \mathrm{~s}^{-1}$ & - \\
\hline $\mathrm{N}$ & $\begin{array}{l}\text { Concentration of nitrogen in the } \\
\text { environment }\end{array}$ & - & $\mu \mathrm{g} \mathrm{N} \mathrm{L}{ }^{-1}$ & - \\
\hline $\mathrm{P}$ & $\begin{array}{l}\text { Concentration of phosphorous in the } \\
\text { environment }\end{array}$ & - & $\mu \mathrm{g} \mathrm{P} \mathrm{L}{ }^{-1}$ & - \\
\hline$w_{\mathrm{X}}$ & Cellular mass of toxic algae & $8.95 \times 10^{-4}$ & $\mu \mathrm{g} \mathrm{C}$ & {$[28]$} \\
\hline$Z$ & Biomass of zooplankton & - & $\mu \mathrm{g} \mathrm{C} \mathrm{L}{ }^{-1}$ & - \\
\hline \multicolumn{5}{|c|}{ Functional responses } \\
\hline$J_{\mathrm{i}}$ & Flux of assimilated substance & & $\begin{array}{l}\mu \mathrm{g} \mathrm{Cd}^{-1}, \mu \mathrm{g} \mathrm{N} \mathrm{d}^{-1} \text {, or } \mu \mathrm{g} \\
\mathrm{P} \mathrm{d}^{-1}\end{array}$ & Eq. (1) \\
\hline$A_{\mathrm{L}}$ & Affinity for light & $3.1 \times 10^{-5}$ & $\mu \mathrm{g} \mathrm{C}\left(\mu \mathrm{E} \mathrm{m} \mathrm{m}^{-2} \mathrm{~s}^{-1}\right)^{-1} \mathrm{~d}^{-1}$ & Calibrated \\
\hline$A_{\mathrm{N}}$ & Affinity for nitrogen & $3 \times 10^{-6}$ & $\mathrm{~L} \mathrm{~d}^{-1}$ & Calibrated \\
\hline$A_{\mathrm{P}}$ & Affinity for phosphorous & $3 \times 10^{-7}$ & $\mathrm{Ld}^{-1}$ & Calibrated \\
\hline$M_{\mathrm{L}}$ & $\begin{array}{l}\text { Max. uptake rate of } \mathrm{C} \text { through } \\
\text { photosynthesis }\end{array}$ & $9.5 \times 10^{-4}$ & $\mu \mathrm{g} \mathrm{C} \mathrm{d}{ }^{-1}$ & Calibrated \\
\hline$M_{\mathrm{N}}$ & Max. uptake rate of $\mathrm{N}$ & $1.1 \times 10^{-4}$ & $\mu \mathrm{g} \mathrm{N} \mathrm{d}^{-1}$ & Calibrated \\
\hline$M_{\mathrm{p}}$ & Max. uptake rate of $\mathrm{P}$ & $1.3 \times 10^{-5}$ & $\mu \mathrm{g} \mathrm{P} \mathrm{d}$ & Calibrated \\
\hline \multicolumn{5}{|c|}{ Costs and toxin production } \\
\hline$R_{\mathrm{C}}$ & Total metabolic cost & - & $\mu \mathrm{g} \mathrm{C} \mathrm{d}^{-1}$ & Eq. (2) \\
\hline$R_{0}$ & Basal respiration rate & $1.07 \times 10^{-4}$ & $\mu \mathrm{g} \mathrm{C} \mathrm{d}{ }^{-1}$ & [29] \\
\hline$\theta$ & Fraction of $\mathrm{N}$ devoted to toxin & - & - & Eq. (10) \\
\hline$T_{\text {pot }}$ & Potential toxin production rate & - & $\mu \mathrm{g} \mathrm{N} \mathrm{d}{ }^{-1}$ & Eq. (3) \\
\hline$T_{r}$ & Actual toxin production rate & - & $\mu \mathrm{g} \mathrm{N} \mathrm{d}^{-1}$ & Eq. (4) \\
\hline $\mathrm{T}$ & Cellular toxin content & - & $\mu \mathrm{g} \mathrm{N}$ cell ${ }^{-1}$ & - \\
\hline$R_{\mathrm{T}}$ & Cost of toxin production & - & $\mu \mathrm{g} \mathrm{C} \mathrm{d}{ }^{-1}$ & Eq. (5) \\
\hline$n_{\mathrm{T}}$ & Material cost of toxin production & 1.23 & $\mu \mathrm{g} \mathrm{C}(\mu \mathrm{g} \mathrm{N})^{-1}$ & Calibrated \\
\hline$r_{\mathrm{T}}$ & Metabolic cost of synthesizing toxin & 2.7 & $\mu \mathrm{g} \mathrm{C}(\mu \mathrm{g} \mathrm{N})^{-1}$ & Calibrated \\
\hline \multicolumn{5}{|c|}{ Predation } \\
\hline$m_{\mathrm{p}}$ & Predation mortality & - & $\mathrm{d}^{-1}$ & Eq. (9) \\
\hline$m_{\mathrm{p}, 0}$ & Mortality constant & 0.008 & $\mathrm{~L}(\mu \mathrm{g} \mathrm{C})^{-1} \mathrm{~d}^{-1}$ & [33] \\
\hline$\beta$ & Reduction in grazing due to toxin & $1.147 \times 10^{5}$ & cells $(\mu \mathrm{g} \mathrm{N})^{-1}$ & Calibrated \\
\hline \multicolumn{5}{|c|}{ Synthesis and growth } \\
\hline$J_{\text {tot }}$ & Total available C flux & - & $\mu \mathrm{g} \mathrm{C} \mathrm{d}{ }^{-1}$ & Eq. (6) \\
\hline$\mu$ & Division rate of algae & - & $\mathrm{d}^{-1}$ & Eq. (7) \\
\hline$r$ & Growth rate of algae & - & $\mathrm{d}^{-1}$ & Eq. (8) \\
\hline$Q_{\mathrm{CN}}$ & $\mathrm{C}: \mathrm{N}$ mass ratio & 5.68 & $\mu \mathrm{g} \mathrm{C}(\mu \mathrm{g} \mathrm{N})^{-1}$ & {$[50]$} \\
\hline$Q_{\mathrm{CP}}$ & $\mathrm{C}: \mathrm{P}$ mass ratio & 41 & $\mu \mathrm{g} \mathrm{C}(\mu \mathrm{g} \mathrm{P})^{-1}$ & {$[50]$} \\
\hline
\end{tabular}

Note: Index i refers to carbon (C) via light-dependent photosynthesis where light intensity is measured in units of $\mu \mathrm{E} \mathrm{m}^{-2} \mathrm{~s}^{-1}$, nitrogen $(\mathrm{N})$ in units of $\mu \mathrm{g} \mathrm{N} \mathrm{L}^{-1}$ or phosphorous (P) in units of $\mu \mathrm{g} \mathrm{P} \mathrm{L}^{-1}$. Calibration of parameters is based on data from laboratory measurements and provided in the 'Model parameterization' section experiments [24], functions only if the defense comes at a cost.

One of the most studied groups of toxic phytoplankton is the dinoflagellate Alexandrium spp. since the toxins it produces, Paralytic Shellfish Toxins (PSTs), have serious effects on humans. The main potential grazers of dinoflagellates are copepods. While the toxin production may be induced by grazer (copepod) cues [13], the production also depends on the nutrient status of the algae. Specifically, when nitrogen or carbon (light) is limiting the PST production is reduced, while nutrient balanced or P-limited cells may produce PSTs at a high rate (growth of P-limited cells decreases while the production of toxins continues) $[25,26]$. PSTs contain large amounts of nitrogen, and so this dependency suggests that the costs of PST production only become obvious when $\mathrm{N}$ or light is limiting, and may 


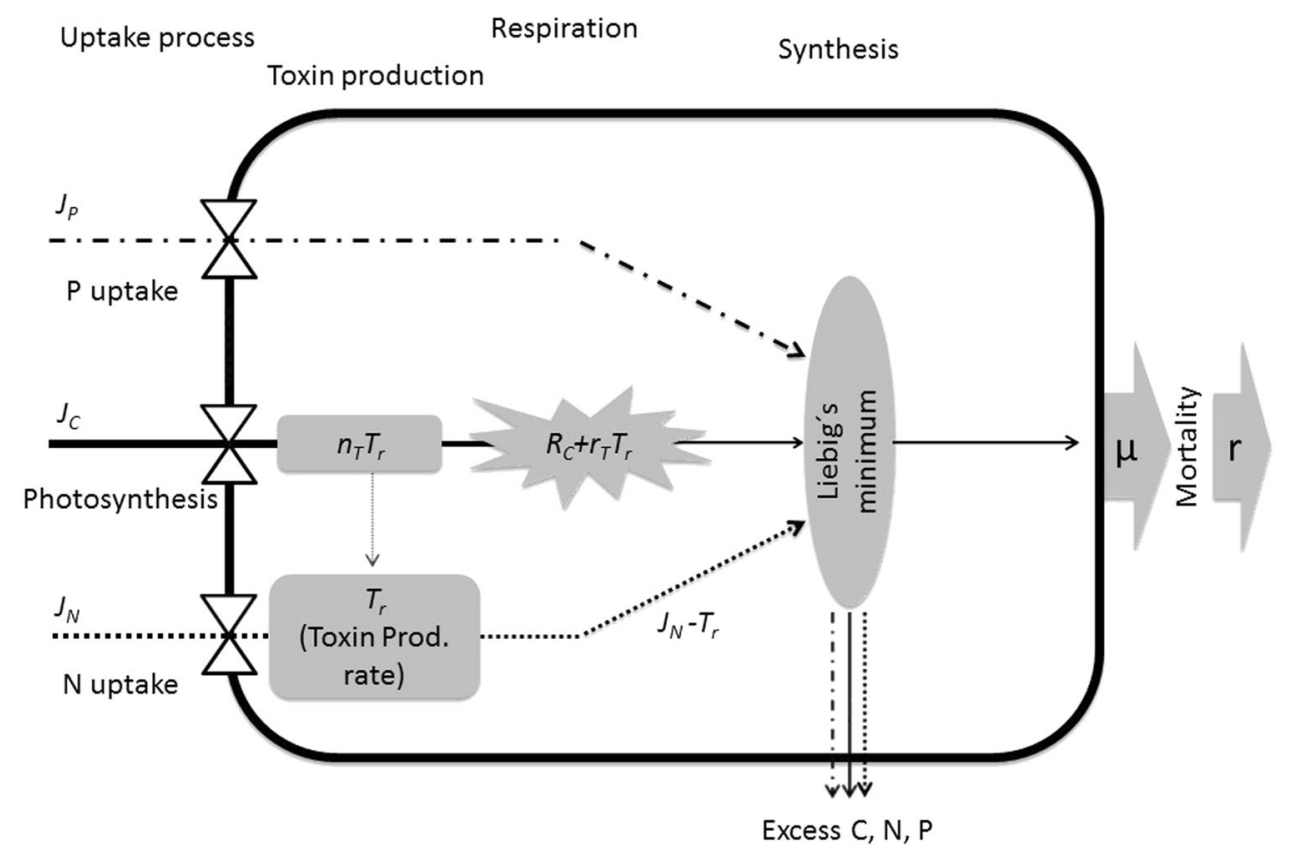

Fig. 1 Schematic representation of the model showing how fluxes of nitrogen (dotted), carbon (solid), and phosphorous (dash-dot) are lost through respiration (gray explosion) and toxin production (gray rectangles), and combined (gray ellipse) to determine growth rate. White triangle symbols represent the functional responses for the uptake mechanisms. $R_{\mathrm{C}}$ represents the respiratory cost that includes the costs of both uptake and mobilization of resources for synthesis and the maintenance of structure. The rate at which toxin is synthesized from
$\mathrm{C}$ and $\mathrm{N}$ is $n_{\mathrm{T}} T_{\mathrm{r}}$, and the respiratory cost of toxin production is $r_{\mathrm{T}} T_{\mathrm{r}}$ where $T_{r}$ is the toxin production rate. The ellipse represents synthesis of biomass from the available $\mathrm{C}, \mathrm{N}$, and $\mathrm{P}$ following Liebig's law of the minimum and constrained by the Redfield ratio $\left(\mu \mathrm{g} \mathrm{C}(\mu \mathrm{g} \mathrm{N})^{-1}=\right.$ 5.68, $\left.\mu \mathrm{g} \mathrm{C}(\mu \mathrm{g} \mathrm{P})^{-1}=41\right)[50]$. In our steady state consideration, the excess amounts of assimilated $\mathrm{C}, \mathrm{N}$, or $\mathrm{P}$ are assumed lost as excess resources. $\mu$ represents the division rate, and $r$ is the population growth rate after subtracting predation mortality from $\mu$ become manifest either as a reduction in growth rate because part of the assimilated $\mathrm{N}$ goes towards PST production; or as a cessation of the production of PSTs in favor of a higher growth rate with a consequent loss of the defense; or a combination of the two.

Here, we explore by means of a simple resource allocation model the costs of chemical defense in phytoplankton, using PST producing dinoflagellate Alexandrium spp. as an example. We consider both energy and material costs of PST production, their dependency on environmental conditions, and the reduction in mortality that is achieved by the defense investments. Through fitness optimization we demonstrate that costs can be substantial, leading to $>20 \%$ reduction in cell division rate, when grazer abundance is high and nitrogen availability is low. We also examine the conditions under which the production of toxins provides maximum benefit to the toxin producing species.

\section{Model description}

The model is based on a resource allocation optimization model modified from Berge et al. [27]. The division rate of phytoplankton depends on the acquisition of three resources, viz. carbon (via photosynthesis), nitrogen (as nitrate), and phosphorous (as phosphate), as well as on metabolic expenses. The cells may invest some of their assimilated nitrogen into toxin production and combust some of their fixed organic carbon to cover costs of toxin synthesis, and in return experience reduced grazing mortality. We search for the investment that maximizes the fitness of the cells, defined as the difference between cell division rate and mortality rate (= net growth rate). We use the model to explore the dependency of division rate, net growth rate, and toxicity on the environmental resource availability and predation risk.

Uptake of carbon, nitrogen, and phosphorous to the cell is described by the symbol $J_{\mathrm{i}}$ (mass flows i being carbon via light-dependent photosynthesis $(\mathrm{C})$, nitrogen $(\mathrm{N})$, or phosphorous (P) in units of $\mu \mathrm{g}$ per day; see Table 1 for central symbols and parameters), and are combined to synthesize new biomass (Fig. 1). Respiratory costs, $R_{\mathrm{C}}$ (units of $\mu \mathrm{g} \mathrm{C}$ per day), include costs of biomass synthesis (including transport) and maintenance of the structure. Toxin is produced at a rate, $T_{\mathrm{r}}$, and implies an additional respiratory cost, $R_{\mathrm{T}}$. Biomass synthesis rate, $J_{\mathrm{tot}}$, is constrained by the stoichiometric balance between carbon, nitrogen, and phosphorous. Finally, we assume that toxins and structure have constant but different stoichiometry. 


\section{Uptake of carbon, nitrogen, and phosphorous}

The potential uptake $J_{\mathrm{i}}$ of resource $\mathrm{i}(\mathrm{C}, \mathrm{N}, \mathrm{P})$ is governed by a standard saturating functional response:

$J_{\mathrm{i}}=M_{\mathrm{i}} \frac{A_{\mathrm{i}} Y_{\mathrm{i}}}{A_{\mathrm{i}} Y_{\mathrm{i}}+M_{\mathrm{i}}}$,

where $A_{\mathrm{i}}$ is the affinity for resource $\mathrm{i}, Y_{\mathrm{i}}$ resource concentration $\left(\mu \mathrm{g} \mathrm{L}^{-1}\right)$, and $M_{\mathrm{i}}$ is the maximum uptake rate.

\section{Costs}

Respiratory costs include costs of both uptake and mobilization of resources for synthesis through each pathway, and the maintenance of the structure. This metabolic cost is assumed to be $30 \%$ of the total carbon budget [28] plus a constant basal respiration $\left(R_{0}\right)$ independent of $J_{\mathrm{C}}$, i.e.,

$R_{\mathrm{C}}=0.3 J_{\mathrm{C}}+R_{0}$.

\section{Rate and cost of toxin production}

Let $\theta$ be the fraction of nitrogen uptake that a toxic phytoplankton cell devotes to toxin production. Then the potential rate of toxin production is (units of $\mu \mathrm{g} \mathrm{N} \mathrm{d}^{-1}$ ):

$T_{\text {pot }}(\theta)=\theta J_{\mathrm{N}}$

As the toxin production needs carbon both for building the toxin molecules and to fuel the respiratory costs of toxin production, the actual toxin production rate may be limited by the available carbon to:

$$
T_{\mathrm{r}}(\theta)=\min \left[T_{\mathrm{pot}}(\theta),\left(J_{\mathrm{C}}-R_{\mathrm{C}}\right) /\left(n_{\mathrm{T}}+r_{\mathrm{T}}\right)\right],
$$

where $n_{\mathrm{T}}$ is the mass of carbon need per mass of nitrogen in the toxin, and $r_{\mathrm{T}}$ is the respiratory cost per nitrogen synthesized into toxins (units of $\mathrm{g} \mathrm{C}\left(\mathrm{g} \mathrm{N}^{-1}\right.$ ).

The total cost of toxin production in terms of carbon then becomes $\left(\mu \mathrm{g} \mathrm{C} \mathrm{d}{ }^{-1}\right)$ :

$$
R_{\mathrm{T}}(\theta)=\left(n_{\mathrm{T}}+r_{\mathrm{T}}\right) T_{\mathrm{r}}(\theta)
$$

\section{Synthesis and growth rate}

The assimilated carbon, nitrogen and phosphorous are combined to synthesize new structure. We assume constant $\mathrm{C}: \mathrm{N}$ mass ratio, $Q_{\mathrm{CN}}$ (units of $\mu \mathrm{g} \mathrm{C}(\mu \mathrm{g} \mathrm{N})^{-1}$ ) and C:P mass ratio, $Q_{\mathrm{CP}}$ (units of $\mu \mathrm{g} \mathrm{C}(\mu \mathrm{g} \mathrm{P})^{-1}$ ) of the cell. The total available carbon for growth is then $J_{\mathrm{C}}-R_{\mathrm{C}}-R_{\mathrm{T}}$ where $J_{\mathrm{C}}$ represents the total uptake of carbon through photosynthesis, and $R_{\mathrm{C}}$ and $R_{\mathrm{T}}$ represent the costs of maintenance and biomass synthesis, and costs of toxin production, respectively. The carbon required to synthesize biomass from nutrients is $Q_{\mathrm{CN}}\left(J_{\mathrm{N}}-T_{\mathrm{r}}\right)$ and $Q_{\mathrm{CP}} J_{\mathrm{P}}$ for nitrate and phosphate, respectively. The growth rate is constrained by the limiting resource (Liebig's law of the minimum) such that the total flux of carbon (and nutrients) available for growth $J_{\text {tot }}$ is:

$$
J_{\mathrm{tot}}(\theta)=\min \left[J_{\mathrm{C}}-R_{\mathrm{C}}-R_{\mathrm{T}}(\theta), \quad Q_{\mathrm{CN}}\left(J_{\mathrm{N}}-T_{\mathrm{r}}(\theta)\right), \quad Q_{\mathrm{CP}} J_{\mathrm{P}}\right] .
$$

Synthesis is not explicitly limited by a maximum synthesis capacity; limitation of synthesis is taken care of by the limitation of uptake of carbon, nitrogen and phosphorous in the functional responses (Eq. 1). The division rate $\mu$ of the cells $\left(\mathrm{d}^{-1}\right)$ is the total flux of carbon divided by the carbon mass of the cell $\left(w_{\mathrm{X}}\right)$ :

$\mu(\theta)=J_{\text {tot }}(\theta) / w_{X}$.

Further subtracting the predation mortality $\left(m_{\mathrm{p}}\right)$ yields the net growth rate $(r)$ :

$r(\theta)=\mu(\theta)-m_{p}(\theta)$

We assume that predation mortality increases linearly with zooplankton biomass $(Z)$, and due to the toxin production, zooplankton reduces its grazing pressure on toxic cells exponentially as:

$m_{\mathrm{p}}(\theta)=m_{\mathrm{p}, 0} Z e^{-\beta \mathrm{T}(\theta)}$,

where $m_{\mathrm{p}, 0}$ is a mortality constant, $\mathrm{T}$ is the cellular toxin content $\left(\mu \mathrm{g} \mathrm{N}\right.$ cell $\left.{ }^{-1}\right)$ estimated as the toxin production rate divided by the cell division rate $\left(=T_{\mathrm{r}} / \mu\right)$, and $\beta$ represents the strength of toxic effect.

The resulting population growth rate, $r(\theta)$, is a measure of the fitness of the phytoplankton and we assume that the cell has the ability to optimize its growth rate by regulating its resource allocation to toxin production such that it maximizes its fitness. The optimal proportion of assimilated $\mathrm{N}$ devoted to toxin production then becomes:

$\theta^{*}=\arg \max _{\theta}\{r(\theta)\}$.

\section{Model parameterization}

Calibration of parameters is based on laboratory measurements on the dinoflagellates Alexandrium minutum and $A$. tamarense as the toxic species, and the copepods Acartia clausi and $A$. tonsa as the grazer zooplankton. To calibrate the basic grazing parameters, we use data for non-toxic strains of $A$. minutum.

\section{Parameters related to phytoplankton division rate $(\mu)$}

We use experimental observations reported in the literature for cell division rate $(\mu)$ of $A$. minutum as a function of light 
Fig. 2 Comparison of division rates $(\mu)$ between available data and model outcome with the calibrated parameters by varying (a) nitrogen $\left(\mathrm{P}=200 \mu \mathrm{g} \mathrm{P} \mathrm{L}{ }^{-1}\right)$ (at three different light intensities $\mathrm{L}=100 \mu \mathrm{E} \mathrm{m}^{-2} \mathrm{~s}^{-1}$, $50 \mu \mathrm{E} \mathrm{m}^{-2} \mathrm{~s}^{-1}, 25 \mu \mathrm{E} \mathrm{m}^{-2} \mathrm{~s}^{-1}$ ) [51], (b) phosphorous $(\mathrm{L}=45$ $\left.\mu \mathrm{E} \mathrm{m} \mathrm{m}^{-2} \mathrm{~s}^{-1}, \mathrm{~N}=200 \mu \mathrm{g} \mathrm{N} \mathrm{L}{ }^{-1}\right)$ [52], and (c) light $(\mathrm{N}=6000 \mu \mathrm{g}$ $\left.\mathrm{N} \mathrm{L}^{-1}, \mathrm{P}=400 \mu \mathrm{g} \mathrm{P} \mathrm{L}^{-1}\right)[51$, 53]. Grazing rate at different toxin concentrations (d). Data for grazing on toxic $A$. tamarense strain CCMP 115 by A. tonsa were used [12]
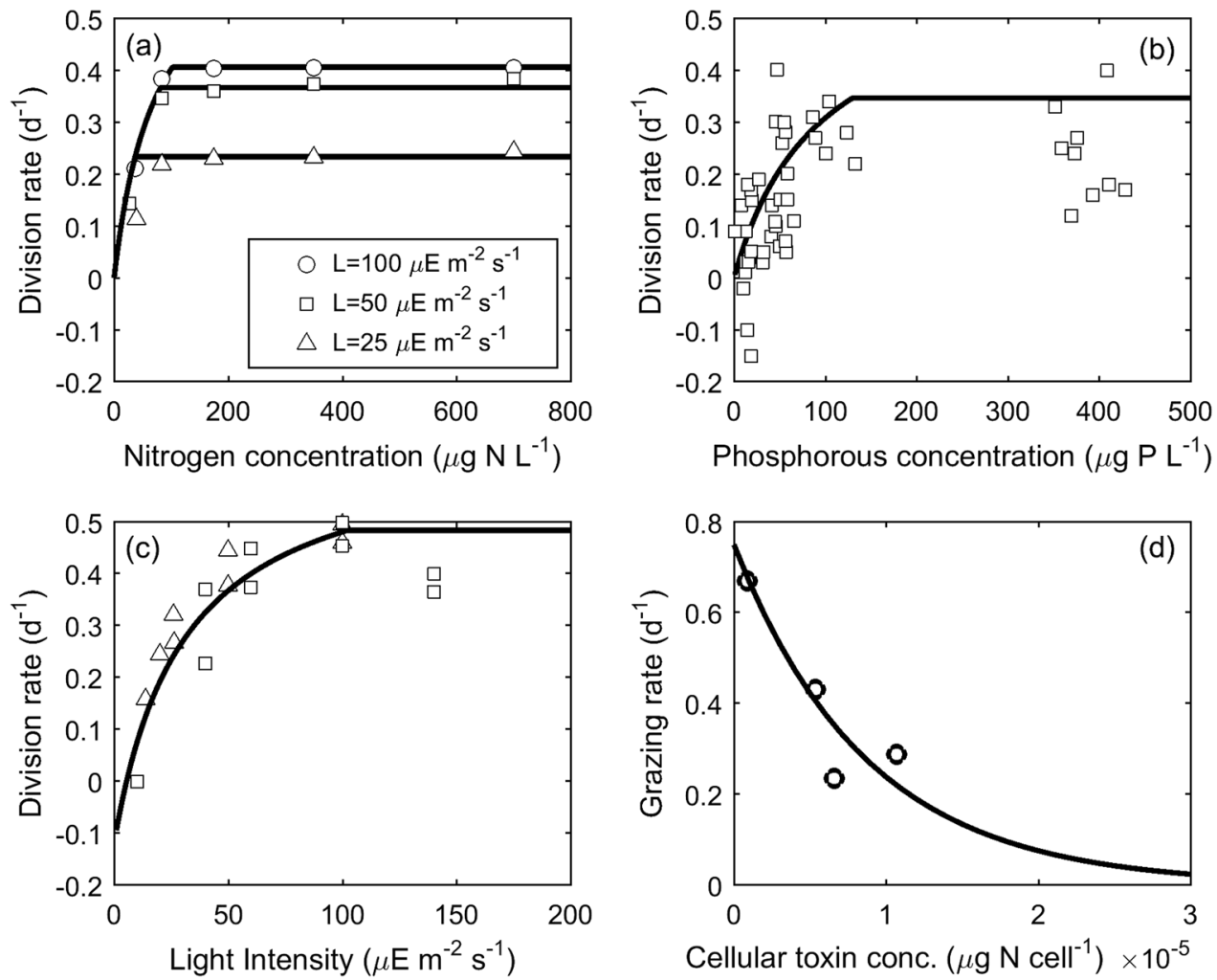

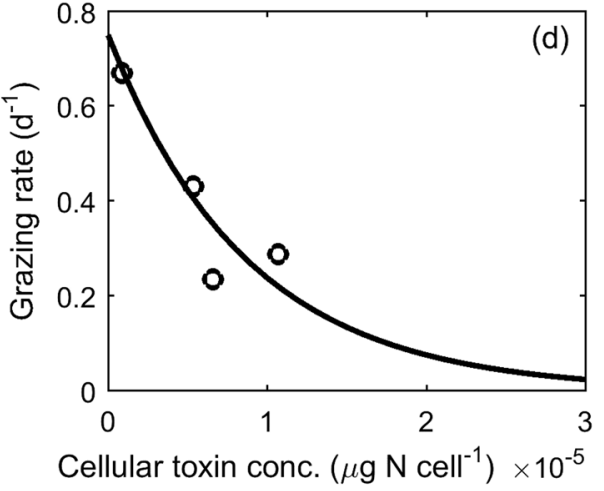

intensity (L) and nutrient concentrations ( $\mathrm{N}$ and $\mathrm{P}$ ) to estimate parameter values for maximum uptake rates $\left(M_{\mathrm{i}}\right)$ and affinities $\left(A_{\mathrm{i}}\right)$ (Fig. 2a-c). While calibrating these parameters a non-toxic strain of $A$. minutum was considered, and as a result, no cost is deducted. For calibration, we adjust the parameters manually to fit the curves with data and keep them close to the existing values of the parameters from other studies (when available). Due to Liebig's minimum law for synthesis (Eq. 6), the synthesis is limited by one of the resources (either $\mathrm{C}$ or $\mathrm{N}$ ) and further growth cannot materialize in spite of the availability of other nonlimiting resource. As a result, growth cannot increase any further.

We use a constant value $1.07 \times 10^{-4} \mu \mathrm{g} \mathrm{C} \mathrm{d} \mathrm{d}^{-1}$ for the basal respiration rate $\left(R_{0}\right)$ taken from the range reported in Frangoulis et al. [29].

\section{Parameters related to the cost of toxin production}

To estimate the two parameters related to the cost of toxin production $\left(n_{\mathrm{T}}, r_{\mathrm{T}}\right)$, we consider the stoichiometry of PSTs and the biochemistry of PST synthesis. PSTs produced by Alexandrium spp. (and other organisms) consist of saxitoxin and multiple derivatives; they are cyclic nitrogenous compounds that are synthesized from amino acid precursors. Here we consider the synthesis of saxitoxin, one of the dominating toxins, from the amino acid glutamate via arginine to estimate the approximate costs of toxin production. The costs are two-fold; i.e., the metabolic cost of biosynthesis, $r_{\mathrm{T}}$, and the cost in terms of material invested in the toxin, $n_{\mathrm{T}}$.

Material investment $\left(n_{\mathrm{T}}\right)$ : The molecular formula of saxitoxin in $\mathrm{C}_{10} \mathrm{H}_{17} \mathrm{~N}_{7} \mathrm{O}_{4}$, that is 10 moles of carbon per 7 moles of nitrogen, or $n_{\mathrm{T}}=(10 \times 12) /(7 \times 14)=1.23 \mu \mathrm{g} \mathrm{C}(\mu \mathrm{g} \mathrm{N})^{-1}$.

Metabolic expenses $\left(r_{\mathrm{T}}\right)$ : Saxitoxin is synthesized from arginine [30], which in turn is typically synthesized from glutamate that in phytoplankton has to be synthesized de novo. The metabolic cost of converting glutamate to arginine is $12 \mathrm{~mol}$ ATP per mol of arginine, and the synthesis of arginine precursors (i.e., glutamate and carbamoyl-P) requires another $32 \mathrm{~mol}$ of ATP, i.e., a total of $44 \mathrm{~mol}$ ATP per mol of arginine [31]. We have no estimate of the cost of synthesizing saxitoxin from arginine (e.g., necessary transcripts and translation to enzymes), as well as costs due to actual or potential autotoxicity (hence we ignore it), but it takes $3 \mathrm{~mol}$ of arginine to synthesize one mol of saxitoxin. Therefore, it requires at least $132 \mathrm{~mol}$ of ATP to synthesize 1 mol of saxitoxin. The respiratory equivalent of ATP synthesis is about 0.235 mol ATP synthesized per liter of oxygen consumed; or about $2 \mathrm{~g}$ of organic carbon combusted per mol of ATP synthesized [32]. Thus, $2 \times 132 \mathrm{~g}$ of organic carbon is respired per mol of toxin synthesized. With $7 \times 14 \mathrm{~g} \mathrm{~N}$ per mol toxin yields an estimate of $r_{\mathrm{T}}=2.7$ $\mu \mathrm{g} C(\mu \mathrm{g} \mathrm{N})^{-1}$. 

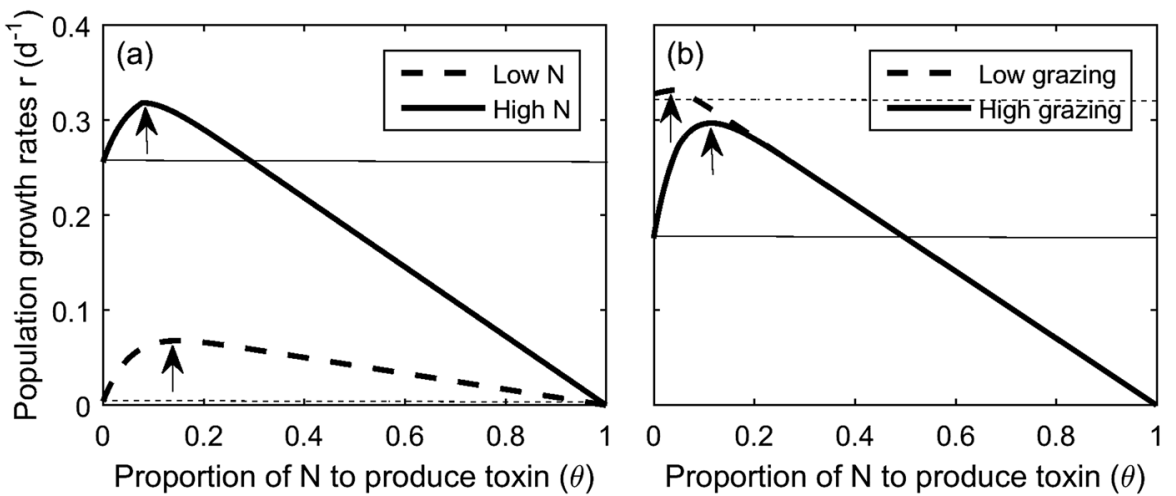

Fig. 3 Population growth rate as a function of the fraction of assimilated nitrogen that is allocated to toxin production (a) at low and high environmental concentration of $\mathrm{N}\left(\mathrm{N}=80 \mu \mathrm{g} \mathrm{N} \mathrm{L}{ }^{-1}\right.$ and $10 \mu \mathrm{g} \mathrm{N} \mathrm{L}-1$ with concentration of grazer $\mathrm{Z}=10 \mu \mathrm{g} \mathrm{C} \mathrm{L}^{-1}$ ), and (b) at high and low concentration of zooplankton $\left(\mathrm{Z}=20 \mu \mathrm{g} \mathrm{C} \mathrm{L}^{-1}\right.$ and $1 \mu \mathrm{g} \mathrm{C} \mathrm{L}^{-1}$ with
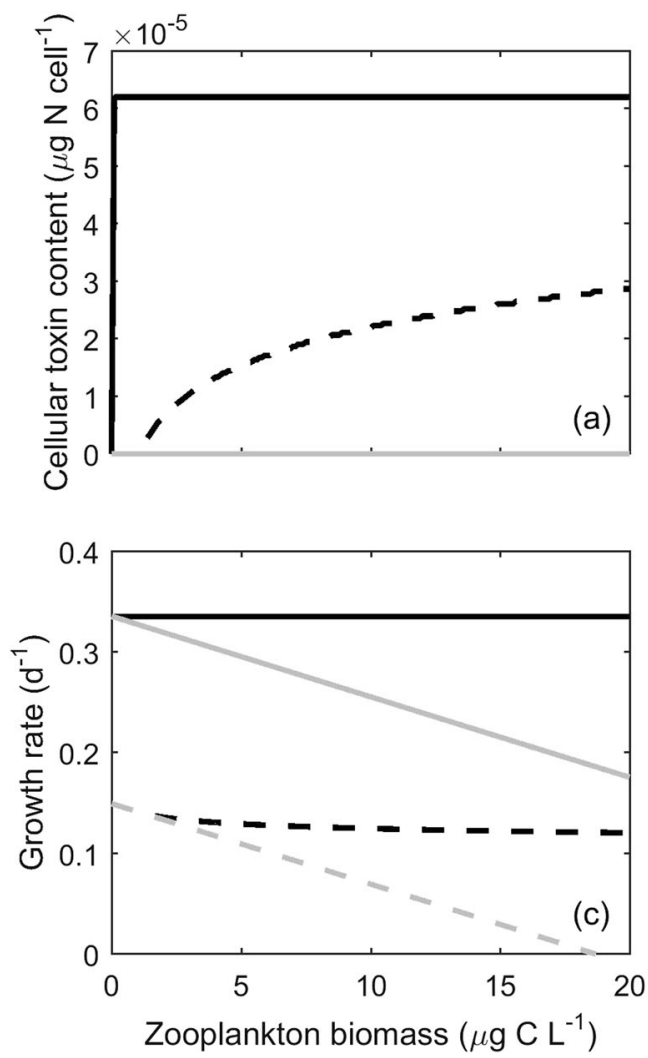

Fig. 4 Optimal cellular toxin content (a), cell division rate (b), population growth rate $(\mathbf{c})$, and predation mortality (d) as a function zooplankton biomass at low $\left(\mathrm{N}=20 \mu \mathrm{g} \mathrm{N} \mathrm{L}^{-1}\right)$ and high $(\mathrm{N}=150 \mu \mathrm{g}$ $\mathrm{N} \mathrm{L}^{-1}$ ) $\mathrm{N}$ concentrations of defended (toxin producing) and

\section{Parameters related to zooplankton feeding}

The parameters related to reduction in feeding on toxic cell $(\beta)$ was calibrated from Teegarden and Cembella [12] who quantified the feeding rate on a toxic strain of A. minutum by A. tonsa as a function of cellular toxin
$\mathrm{N}=75 \mu \mathrm{g} \mathrm{N} \mathrm{L}^{-1}$ ). The maximum of the curves shows the optimal allocation strategy $\left(\theta^{*}\right)$ (marked by arrows). Thin lines represent growth rates in the absence of toxin production. Other resources are

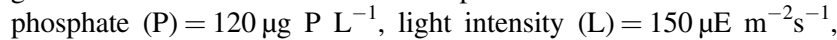
and phytoplankton biomass $(\mathrm{X})=90 \mu \mathrm{g} \mathrm{C} \mathrm{L}^{-1}$
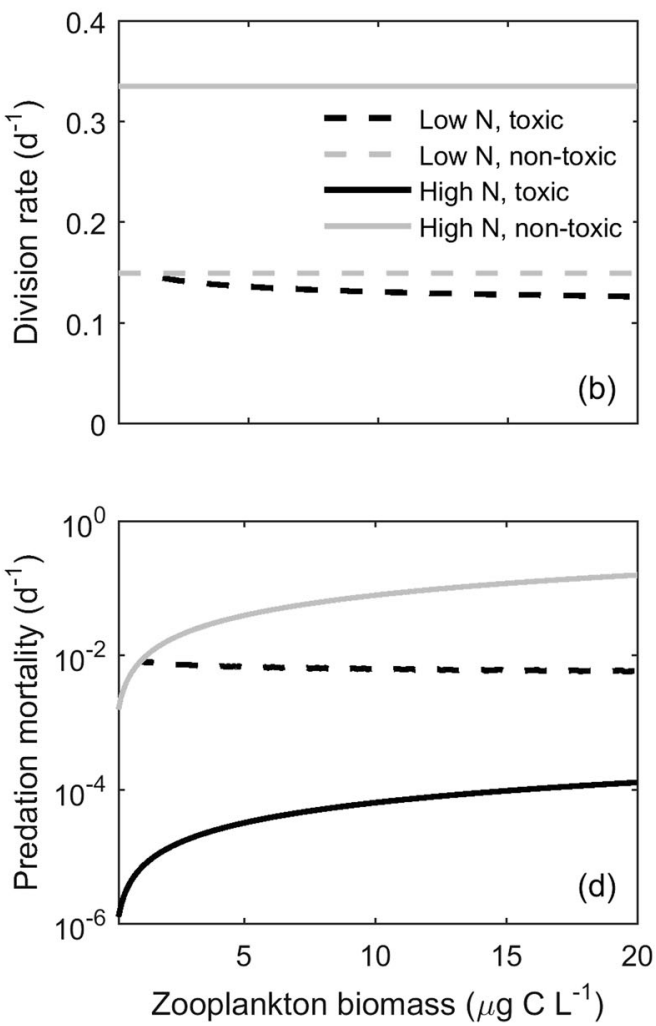

undefended cells (non-toxic strain). Curves of division rates for defended and undefended cells under high $\mathrm{N}$ concentration lie on top of each other. Light intensity $\mathrm{L}=150 \mu \mathrm{E} \mathrm{m}^{-2} \mathrm{~s}^{-1}$ and phosphorous concentration $\mathrm{P}=120 \mu \mathrm{g} \mathrm{P} \mathrm{L}^{-1}$ in all plots

content ( $\mu \mathrm{g} \mathrm{N}$ cell $\left.{ }^{-1}\right)$. We fit Eq. 9 to the experimental data to estimate $\beta$ (Fig. 2 d). We use $8.95 \times 10^{-4}$ as the cellular carbon content of A. minutum [28], and chose the value of the mortality constant $\left(m_{\mathrm{p}, 0}\right)$ as $0.008 \mathrm{~L}$ $(\mu \mathrm{g} \mathrm{C})^{-1} \mathrm{~d}^{-1}$ based on the clearance rate of A. tonsa [33]. 

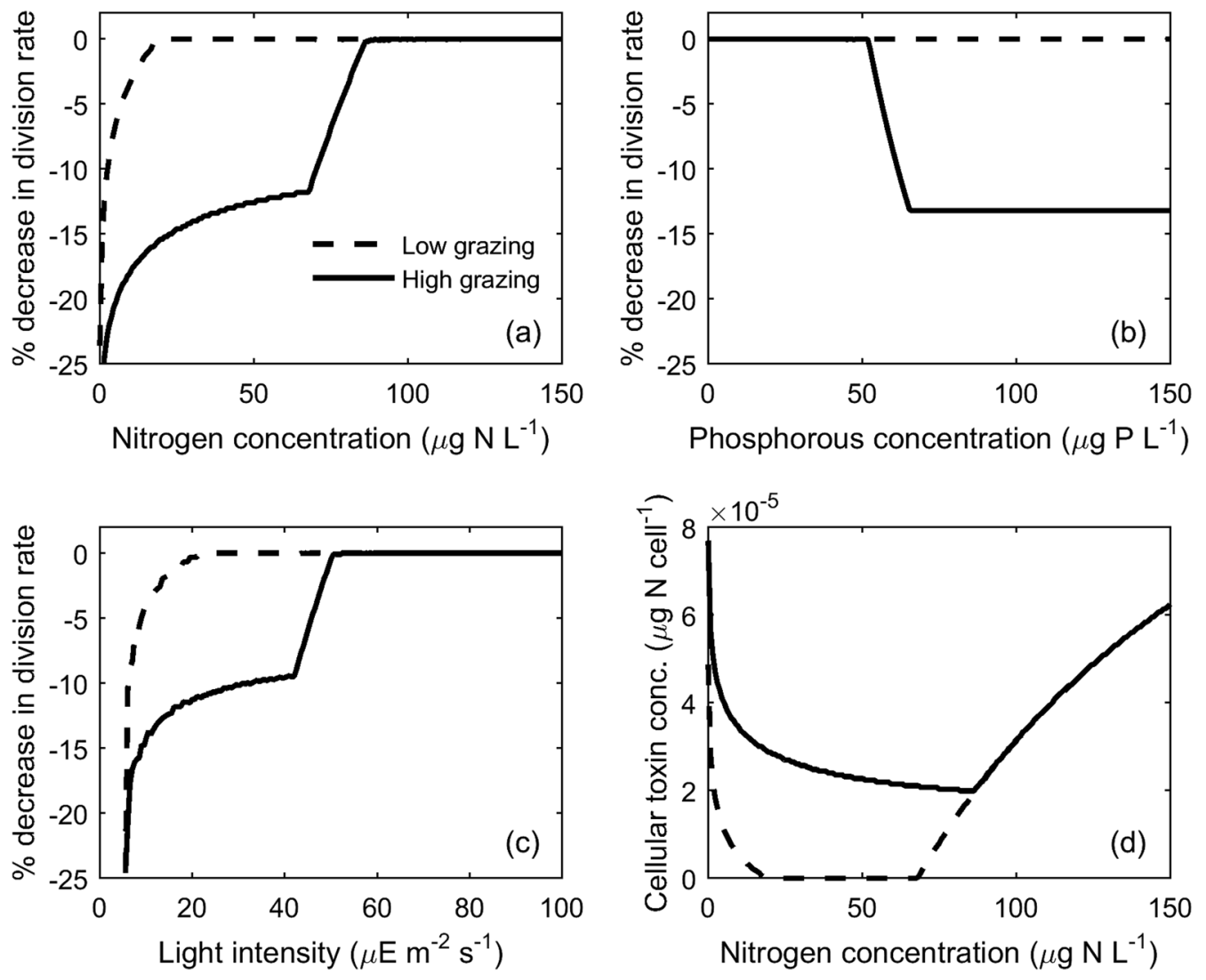

Fig. 5 Relative reduction in cell division rate as a function of nitrogen concentration $\left(\mathrm{L}=150 \mu \mathrm{E} \mathrm{m}^{-2} \mathrm{~s}^{-1}, \mathrm{P}=120 \mu \mathrm{g} \mathrm{P} \mathrm{L}^{-1}\right)$ (a), phosphorous concentration $\left(\mathrm{L}=150 \mu \mathrm{E} \mathrm{m}^{-2} \mathrm{~s}^{-1}, \mathrm{~N}=40 \mu \mathrm{g} \mathrm{N} \mathrm{L} \mathrm{N}^{-1}\right)$ (b), and light intensities $\left(\mathrm{N}=120 \mu \mathrm{g} \mathrm{N} \mathrm{L}^{-1}, \mathrm{P}=120 \mu \mathrm{g} \mathrm{P} \mathrm{L}^{-1}\right)(\mathbf{c})$ at high $(\mathrm{Z}$

$\left.=20 \mu \mathrm{g} \mathrm{C} \mathrm{L}^{-1}\right)$ and low $\left(\mathrm{Z}=1 \mu \mathrm{g} \mathrm{C} \mathrm{L}^{-1}\right)$ zooplankton biomasses. Cellular toxin content as a function of $\mathrm{N}$ at high and low zooplankton biomasses (d)

\section{Results}

\section{Optimal allocation strategy}

The optimal allocation of nitrogen to toxin production is the one that yields the highest population growth rate (Fig. 3). The optimal allocation of $\mathrm{N}$ to toxin production increases with decreasing environmental nitrogen availability and increasing concentration of zooplankton (Fig. 3). As a result, the investment in defense-toxin production-in toxic dinoflagellates varies with both $\mathrm{N}$-availability and grazing pressure, with implications to cell division rate, grazing mortality rate, and population growth rate (Figs. 47).

\section{Toxin production, grazing mortality, and cost of defense}

At high $\mathrm{N}$ concentrations, the cells produce toxin whenever zooplankton is present but production ceases in the absence of grazers (Fig. 4a). Note that for simplicity we assume that

toxin production rate becomes zero when there is no grazer. In contrast, at low $\mathrm{N}$, phytoplankton produce toxins only when zooplankton biomass exceeds a threshold concentration, and the cellular toxin content increases with the biomass of the zooplankton (Figs. 4a, 6b).

Defended cells experience lower grazing mortality than undefended cells especially when nitrogen availability is high and zooplankton concentration is low (Fig. 4d) as cellular toxin content remains high (Fig. 4a). Taken together the grazing mortality increases with zooplankton density and decreases with availability of nitrogen.

The cost of the defense can be quantified as a reduction in the cell division rate of defended relative to undefended cells. This cost is significant only at high zooplankton biomass and/or low nitrogen availability (Figs. 4b, 5a) and increases with increasing zooplankton biomass and decreasing nitrogen concentration (Fig. 6c, d). At realistically high zooplankton biomass and realistically low nitrogen availability, cell division rate may be reduced by more than $20 \%$. At high nitrogen concentrations, the cells produce toxins from the excess nitrogen (not used for 

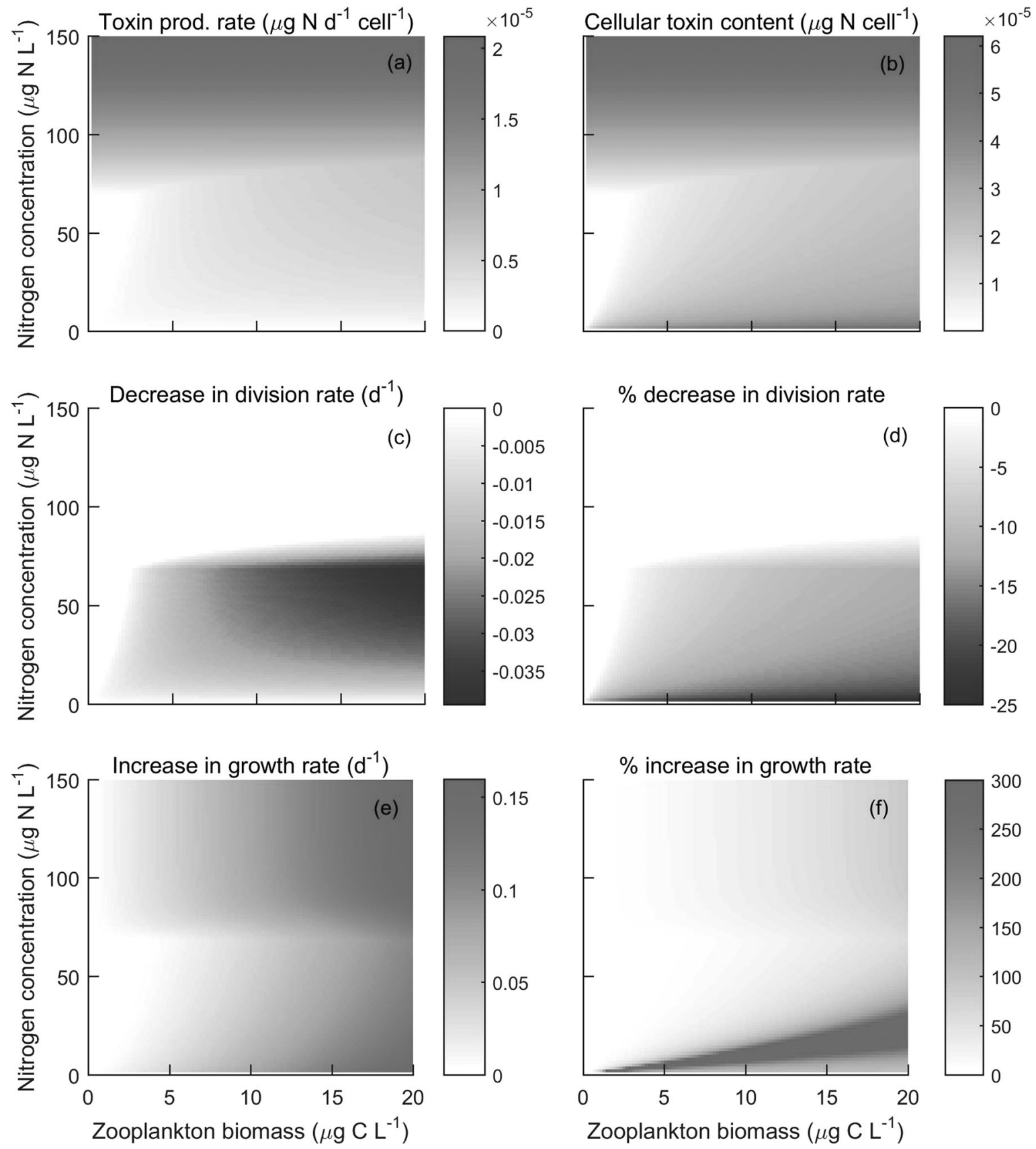

Fig. 6 Surface plots of toxin production rate (a), and cellular toxin content (b), as well as absolute and relative changes in cell division rate $\left(\mu\left(\theta^{*}\right)-\mu(\theta=0)\right)$ and $\left.\left(\mu\left(\theta^{*}\right)-\mu(\theta=0)\right) \times 100 / \mu(\theta=0)\right)(\mathbf{c}, \mathbf{d})$, and population growth rates $\left(g\left(\theta^{*}\right)-g(\theta=0)\right.$ and $\left(g\left(\theta^{*}\right)-g(\theta=0)\right) \times 100 / g$

growth) and therefore the costs are, of course, unmeasurably low (Fig. 6d). The net outcome of the defense investment is that defended cells have similar or higher population growth rates (fitness) than undefended cells under all nutrient conditions (Fig. 4c). The absolute enhancement is largest at high $\mathrm{N}$ (Fig. 6e) whereas the relative advantage is most pronounced at low $\mathrm{N}$ and high zooplankton biomass (Fig. 6f).

\section{Effects of $P$ and light limitation}

If phosphate or light rather than nitrogen limit cell growth, $\mathrm{N}$ is in excess and the excess $\mathrm{N}$ can be allocated to toxin production and the cells consequently become well defended. Figure $7 \mathrm{a}, \mathrm{b}$ display the effects of light limitation on toxin production and cellular toxin contents, respectively. There are two regions in this parameter space: the left region where light 

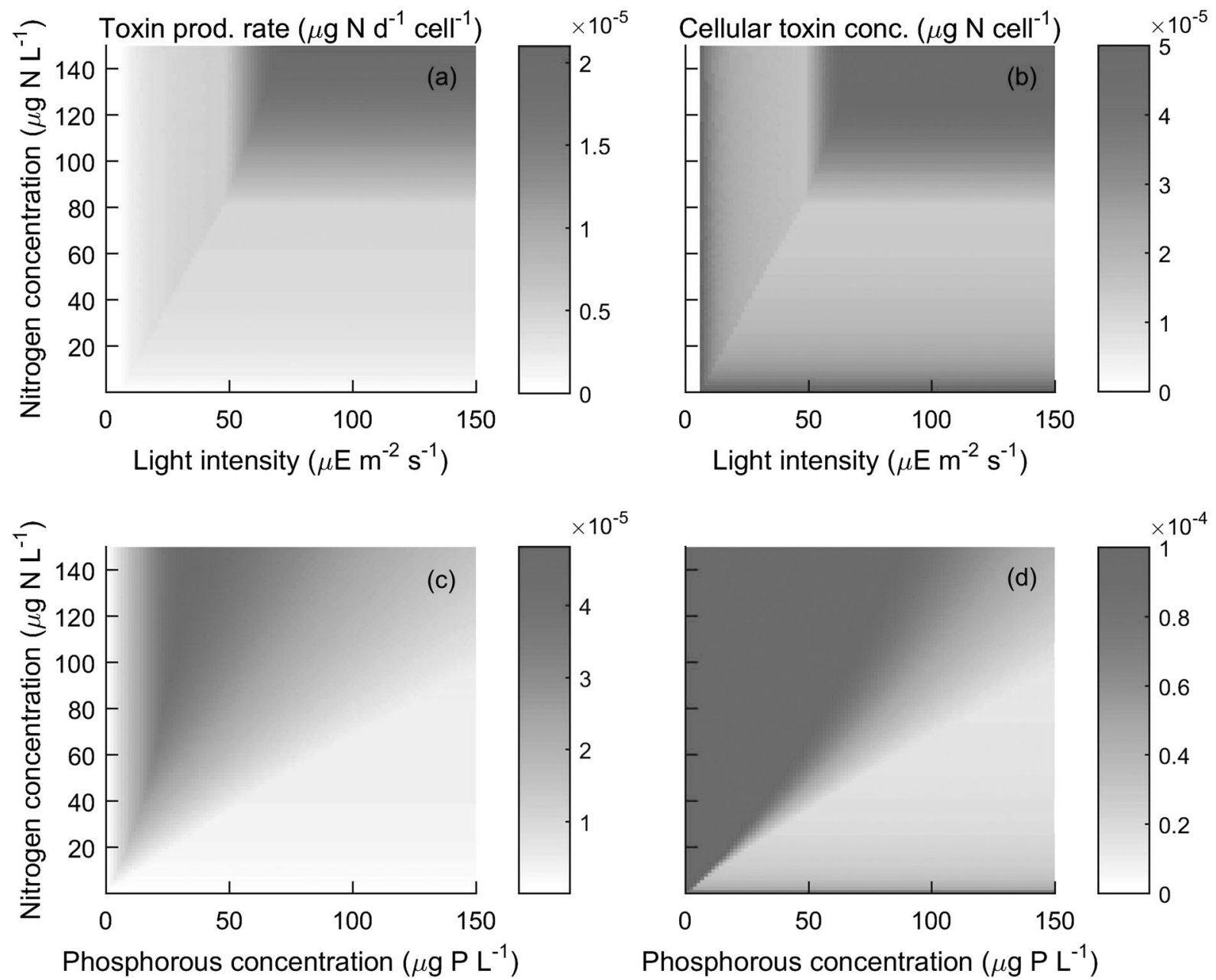

Fig. 7 Surface plots of toxin production rate (a), and cellular toxin content (b) as a function of $\mathrm{N}$-availability and light intensity. Zoo-

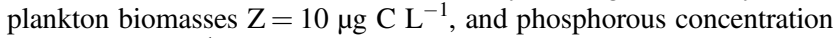
$\mathrm{P}=120 \mu \mathrm{g} \mathrm{P} \mathrm{L}^{-1}$ in both plots. Surface plots of toxin production rate

(c), and cellular toxin content (d) as a function of $\mathrm{N}$ and P-availability. Zooplankton biomasses $\mathrm{Z}=10 \mu \mathrm{g} \mathrm{C} \mathrm{L}^{-1}$, and light intensity $\mathrm{L}=150$ $\mu \mathrm{E} \mathrm{m} \mathrm{m}^{-2} \mathrm{~s}^{-1}$ in both plots

is limiting and toxin production increases with light intensity while toxin content decreases with light intensity; and the right region, where nitrogen is limiting and both toxin production and cellular toxin content are independent of light intensity. Toxin production and cellular contents similarly vary in the nitrogen-phosphorous parameter space, between phosphorous limitation at low $\mathrm{P}$ and nitrogen limitation at high P (Fig. 7c, d). Under all conditions, cellular toxin contents increase with decreasing ambient $P$.

\section{Sensitivity analysis of $\beta$ and $r_{T}$}

Since the parameter $\beta$ was calibrated based on only four available data points (Fig. 2d), we perform a sensitivity analysis by varying $\beta$, which represents the reduction in zooplankton grazing due to cellular toxin (see supplementary material fig. A1). Overall, the qualitative patterns described above are robust to changes in $\beta$. When nitrogen concentrations are high,

there is no observable change in cellular toxin concentration with varying $\beta$ as organisms produce toxins at their maximum rate and consequently division rates remain same. However, due to the increase in predation pressure with decreasing $\beta$, population growth rate decreases. On the other hand, with decrease in nitrogen concentrations, organisms produce more toxin with decrease in $\beta$, leading to reduction in division rates, as well as growth rates.

Similarly, varying the parameter $r_{\mathrm{T}}$, representing the metabolic cost of synthesizing toxin, does not lead to observable changes in the system dynamics (see supplementary material fig. A2).

\section{Discussion}

Experiments have demonstrated that PST producing dinoflagellates become less toxic when $\mathrm{N}$-starved, that toxin 
content is high in exponentially growing cells in N:P balanced environments, and that the cells become most toxic when P-limited [20, 26, 34-36]. Light-limited cells also accumulate more toxins [37] and toxin production is enhanced in the presence of grazer cues [13]. Our model qualitatively reproduces all these observations.

The model further conforms with the experimental observation that the cost of toxin production, quantified as a reduction in cell division rate of toxin-producing cells compared to cells or strains that produce less or no toxins, is negligible when resources, mainly $\mathrm{N}$ and light, are plentiful $[3,13]$. However, when light or nitrogen are limiting cell growth, and when grazers are abundant, we predict that the cost of investing in toxin production may be substantial and lead to $>20 \%$ reduction in cell division rate. There is evidence for other defense mechanisms in phytoplankton where the cost of the defense only materializes when resources are limiting [38-40]. However, the prediction of costs of toxin production still remains to be tested experimentally. The costs of the investment are two-fold: (i) the cells need nitrogen to build toxin molecules, and this requirement compete with the nitrogen investment in cell structure and growth. While the nitrogen requirement for toxin production is small in absolute terms, leading John and Flynn [20] to consider it trivial, it becomes significant when nitrogen is limiting, and may eventually lead to a total shut down of toxin production. (ii) The cells further need energy for the synthesis of toxins, and this energy eventually comes from photosynthesis. This is why toxin production rate increases with light intensity when light is the limiting resource. In this situation, cell division rate increases faster than toxin production rate with increasing light, and therefore cellular toxin content decreases with increasing light, an effect and a mechanism in agreement with experimental observations [37].

The environmental conditions that promote cell toxicity, i.e., high grazer biomass, actually coincide with the time of the year when nitrogen is the most limiting resource in temperate shelf regions. Thus, zooplankton (copepod) biomass is at its seasonal maximum during summer and may easily exceed $10-100 \mu \mathrm{g} \mathrm{C} \mathrm{L}^{-1}$ [41], which will impose a high predation mortality and thus induce high cell toxicity. At this time of the year, concentrations of inorganic nitrogen in surface waters in temperate shelf regions are low, typically below $1-10 \mu \mathrm{g} \mathrm{N} \mathrm{L}^{-1}$ [42, 43], and under these conditions the model predicts that the cost of toxin production is substantial, leading to $>20 \%$ decrease in cell division rate. However, the investment in defense pays off since defended cells experience lower grazing mortality, and may consequently have net growth rates up to twice or more of that of undefended cells (e.g., Fig. 6f). If the toxins have deterrent rather than toxic effects, i.e., preventing the toxic cells from being consumed rather than killing grazers that do consume the cells $[10,11,44]$, then the toxic cells may have a competitive advantage and a monospecific bloom may develop. Indeed, blooms of toxic algae typically occur during summer [45], which is consistent with these considerations.

Furthermore, the toxic species can also gain growth advantage under high nitrogen and high grazer biomass, as growth rates can be doubled due to the benefit provided by toxin production at a negligible production cost (Fig. 6d, f). Such situations are comparable with many coastal areas where N:P ratios remain considerably high due to erratic input of nitrogen from human activities, and can consequently result in toxic blooms [46]. Thus, potentially toxic species can also become toxic when exposed to high $\mathrm{N}$ regime caused by eutrophication.

The success of toxic bloom formation also depends on the evolutionary history of zooplankton grazer and toxic species [39]. Evidence from both fresh waters and marine waters shows that grazers can evolve full or partial resistance against the toxic algae $[47,48]$. Our results suggest that cellular toxin content will increase in the presence of toxin-resistant grazers as will the costs (see supplementary material fig. A1). However, if the benefits in terms of reduced grazing mortality vanish due to grazer resistance, the possibility of success of the toxic species in terms of forming bloom will be reduced or disappear.

Many phytoplankton species have evolved what is supposed to be defense mechanisms to avoid or reduce predation, ranging from hard shells and spines, to evasive behaviors and toxin production, and such defenses may have significant implications on predator-prey interactions, population dynamics, and diversity of phytoplankton communities [49]. However, the trade-offs are rarely quantified and often not even documented. While there is increasing evidence that toxin-production in many cases provides partial protection from grazing in dinoflagellates, the costs have hitherto not been properly quantified. The currencies of benefits and costs are growth and mortality. Here, we have shown that the costs are not only strongly dependent on the concentration of grazers but also on the resource availability, and that the realized costs in nature are typically highest during summer when the defense is most needed. The delicate balance between costs, benefits, and resource availability not only explains why the defense is inducible but also has implications for the timing of toxic algal blooms. Further studies on costs and benefits of toxin production are needed to experimentally test our model predictions (e.g., toxin production and growth under sufficient and deficient resources), and for deeper understanding of the mechanisms and evolution of inducible toxin production. At present, very little is known about the consequences of inducible toxin production on the community level in complex communities. 
Future work should be devoted towards investigating the complex integrated ecological issues of inducible toxin production, species diversity, and food web structure.

Acknowledgements The Centre for Ocean Life is supported by the Villum Foundation. S.C. was supported by the H. C. Ørsted COFUND postdoc fellowship and additional support was received from the Gordon and Betty Moore Foundation through award \#5479.

\section{Compliance with ethical standards}

Conflict of interest The authors declare that they have no conflict of interest.

\section{References}

1. Blossom HE, Andersen NG, Rasmussen SA, Hansen PJ. Stability of the intra- and extracellular toxins of Prymnesium parvum using a microalgal bioassay. Harmful Algae. 2014;32:11-21.

2. Legrand C, Rengefors K, Fistarol GO, Granéli E. Allelopathy in phytoplankton-biochemical, ecological and evolutionary aspects. Phycologia. 2003;42:406-19.

3. John U, Tillmann U, Hülskötter J, Alpermann TJ, Wohlrab S, Van De Waal DB. Intraspecific facilitation by allelochemical mediated grazing protection within a toxigenic dinoflagellate population. Proc R Soc B Biol Sci. 2015;282:1-9.

4. Turner JT. Planktonic marine copepods and harmful algae. Harmful Algae. 2014;32:81-93.

5. Colin SP, Dam HG. Effects of the toxic dinoflagellate Alexandrium fundyense on the copepod Acartia hudsonica: a test of the mechanisms that reduce ingestion rates. Mar Ecol Prog Ser. 2003;248:55-65.

6. Driscoll WW, Hackett JD, Ferrière R. Eco-evolutionary feedbacks between private and public goods: evidence from toxic algal blooms. Ecol Lett. 2016;19:81-97.

7. Blossom HE, Daugbjerg N, Hansen PJ. Toxic mucus traps: a novel mechanism that mediates prey uptake in the mixotrophic dinoflagellate Alexandrium pseudogonyaulax. Harmful Algae. 2012;17:40-53.

8. Sheng J, Malkiel E, Katz J, Adolf JE, Place AR. A dinoflagellate exploits toxins to immobilize prey prior to ingestion. Proc Natl Acad Sci. 2010;107:2082-7.

9. Wolfe GV. The chemical defense ecology of marine unicellular plankton: constraints, mechanisms, and impacts. Biol Bull. 2000;198:225-44.

10. Xu J, Nielsen LT, Kiørboe T. Foraging response and acclimation of ambush feeding and feeding-current feeding copepods to toxic dinoflagellates. Limnol Oceanogr. 2018; in press, https://doi.org/ 10.1002/lno.10782.

11. Xu J, Hansen JP, Nielsen TL, Krock B, Tillmann U, Kiørboe T. Distinctly different behavioral responses of a copepod, Temora longicornis, to different strains of toxic dinoflagellates, Alexandrium spp. Harmful Algae. 2017;62:1-9.

12. Teegarden GJ, Cembella AD. Grazing of toxic dinoflagellates, Alexandrium spp, by adult copepods of coastal Maine: Implications for the fate of paralytic shellfish toxins in marine food webs. J Exp Mar Bio Ecol. 1996;196:145-76.

13. Selander E, Thor P, Toth G, Pavia H. Copepods induce paralytic shellfish toxin production in marine dinoflagellates. Proc R Soc B Biol Sci. 2006;273:1673-80.

14. Schultz M, Kiørboe T. Active prey selection in two pelagic copepods feeding on potentially toxic and non-toxic dinoflagellates. J Plankton Res. 2009;31:553-61.
15. Sykes PF, Huntley ME. Acute physiological reactions of Calanus pacificus to selected dinoflagellates: Direct observations. Mar Biol. 1987;94:19-24.

16. Selander E, Fagerberg T, Wohlrab S, Pavia H. Fight and flight in dinoflagellates? Kinetics of simultaneous grazer-induced responses in Alexandrium tamarense. Limnol Oceanogr. 2012;57:58-64.

17. Senft-Batoh CD, Dam HG, Shumway SE, Wikfors GH. A multiphylum study of grazer-induced paralytic shellfish toxin production in the dinoflagellate Alexandrium fundyense: a new perspective on control of algal toxicity. Harmful Algae. 2015;44:20-31.

18. Harðardóttir S, Pančić M, Tammilehto A, Krock B, Møller EF, Nielsen TG, et al. Dangerous relations in the Arctic marine food web: Interactions between toxin producing Pseudo-nitzschia diatoms and Calanus copepodites. Mar Drugs. 2015;13:3809-35.

19. Karban R. The ecology and evolution of induced resistance against herbivores. Funct Ecol. 2011;25:339-47.

20. John EH, Flynn KJ. Modelling changes in paralytic shellfish toxin content of dionoflagellates in response to nitrogen and phosphorus supply. Mar Ecol Prog Ser. 2002;225:116-47.

21. Thingstad TF, Våge S, Storesund JE, Sandaa R-A, Giske J. A theoretical analysis of how strain-specific viruses can control microbial species diversity. Proc Natl Acad Sci. 2014;111:7813-8.

22. Våge $S$, Storesund JE, Giske J, Thingstad TF. Optimal defense strategies in an idealized microbial food web under trade-off between competition and defense. PLoS ONE. 2014;9:e101415.

23. Strauss SY, Rudgers JA, Lau JA, Irwin RE. Direct and ecological costs of resistance to herbivory. Trends Ecol Evol. 2002;17:278-85.

24. Leibold MA, Hall SR, Smith VH, Lytle DA. Herbivory enhances the diversity of primary producers in pond ecosystems. Ecology. 2017;98:48-56.

25. Anderson DM, Kulis DM, J. J. S, Hall S, Lee C. Dynamics and physiology of saxitoxin production by the dinoflagellate Alexandrium spp. Mar Biol. 1990;104:511-24.

26. John EH, Flynn KJ. Growth dynamics and toxicity of Alexandrium fundyense (Dinophyceae): The effect of changing N:P supply ratios on internal toxin and nutrient levels. Eur J Phycol. 2000;35:11-23.

27. Berge T, Chakraborty S, Hansen PJ, Andersen KH. Modeling succession of key resource-harvesting traits of mixotrophic plankton. ISME J. 2017;11:212-23.

28. López-Sandoval DC, Rodríguez-Ramos T, Cermeño P, Sobrino C, Marañón E. Photosynthesis and respiration in marine phytoplankton: Relationship with cell size, taxonomic affiliation, and growth phase. J Exp Mar Bio Ecol. 2014;457:151-9.

29. Frangoulis C, Carlotti F, Eisenhauer L, Zervoudaki S. Converting copepod vital rates into units appropriate for biogeochemical models. Prog Oceanogr. 2010;84:43-51.

30. Kellmann R, Mihali TK, Young JJ, Pickford R, Pomati F, Neilan BA. Biosynthetic intermediate analysis and functional homology reveal a saxitoxin gene cluster in cyanobacteria. Appl Environ Microbiol. 2008;74:4044-53.

31. Atkinson DE. Cellular Energy Metabolism and Its Regulation. Academic Press, New York, 1977.

32. Kiørboe T, Møhlenberg F, Hamburger K. Bioenergetics of the planktonic copepod Acartia tonsa: relation between feeding, egg production and respiration, and composition of specific dynamic action. Mar Ecol Prog Ser. 1985;26:85-97.

33. Saiz E, Kiørboe T. Predatory and suspension feeding of the copepod Acartia tonsa in turbulent environments. Mar Ecol Prog Ser. 1995;122:147-58.

34. Boyer GL, Sullivan JJ, Andersen RJ, Harrison PJ, Taylor FJR. Effects of nutrient limitation on toxin production and composition 
in the marine dinoflagellate Protogonyaulax tamarensis. Mar Biol. 1987;128:123-8.

35. Han M, Lee H, Anderson DM, Kim B. Paralytic shellfish toxin production by the dinoflagellate Alexandrium pacificum (Chinhae Bay, Korea) in axenic, nutrient-limited chemostat cultures and nutrient-enriched batch cultures. Mar Pollut Bull. 2016;104:34-43.

36. Murata A, Nagashima Y, Taguchi S. N:P ratios controlling the growth of the marine dinoflagellate Alexandrium tamarense: Content and composition of paralytic shellfish poison. Harmful Algae. 2012;20:11-8.

37. Ogata T, Ishimura T, Kodama M. Effect of water temperature and light intensity on growth rate and toxicity change in Protogonyaulax tamarensis. Mar Biol. 1987;95:217-20.

38. Zhu X, Wang J, Chen Q, Chen G, Huang Y, Yang Z. Costs and trade-offs of grazer-induced defenses in Scenedesmus under deficient resource. Sci Rep. 2016;6:1-10.

39. Yoshida T, Hairston NG, Ellner SP. Evolutionary trade-off between defence against grazing and competitive ability in a simple unicellular alga, Chlorelia vulgaris. Proc R Soc B-Biol Sci. 2004;271:1947-53.

40. Yoshida T, Jones LE, Ellner SP, Fussmann GF, Hairston NG. Rapid evolution drives ecological dynamics in a predator-prey system. Nature. 2003;424:303-6.

41. Kiørboe T, Nielsen TG. Regulation of zooplankton biomass and production in a temperate, coastal ecosystem. 1. Copepods. Limnol Ocean. 1994;39:493-507.

42. Andersson L. Trends in nutrient and oxygen concentrations in the Skagerrak-Kattegat. J Sea Res. 1996;35:63-71.

43. Brockmann UW, Topcu DH. Nutrient atlas of the central and northern North Sea. Federal Environmental Agency, Berlin, Germany. 2002.
44. Teegarden GJ. Copepod grazing selection and particle discrimination on the basis of PSP toxin content. Mar Ecol Prog Ser. 1999;181:163-76.

45. Heisler J, Glibert PM, Burkholder JM, Anderson DM, Cochlan W, Dennison WC, et al. Eutrophication and harmful algal blooms: A scientific consensus. Harmful Algae. 2008;8:3-13.

46. Hallegraeff GM. A review of harmful algal blooms and their apparent global increase. Phycologia. 1993;32:79-99.

47. Gilbert JJ. Differential effects of Anabaena affinis on Cladocerans and Rotifers: mechanisms and implications. Ecology. 1990;71:1727-40.

48. Colin SP, Dam HG. Latitudinal differentiation in the effects of the toxic dinoflagellate Alexandrium spp. on the feeding and reproduction of populations of the copepod Acartia hudsonica. Harmful Algae. 2002;1:113-25.

49. Pančić M, Kiørboe T. Phytoplankton defence mechanisms: traits and trade-offs. Biol Rev. 2018;93:1269-303.

50. Redfield AC. The biological control of chemical factors in the environment. Am Sci. 1958;46:205-21. Sigma Xi, The Scientific Research HonorSociety.

51. Chang FH, McClean M. Growth responses of Alexandrium minutum (Dinophyceae) as a function of three different nitrogen sources and irradiance. New Zeal J Mar Freshw Res. 1997;31:1-7.

52. Ignatiades L, Gotsis-Skretas O, Metaxatos A. Field and culture studies on the ecophysiology of the toxic dinoflagellate Alexandrium minutum (Halim) present in Greek coastal waters. Harmful Algae. 2007;6:153-65.

53. Lim PT, Leaw CP, Usup G, Kobiyama A, Koike K, Ogata T. Effects of light and temperature on growth, nitrate uptake, and toxin production of two tropical dinoflagellates: Alexandrium tamiyavanichii and Alexandrium minutum (Dinophyceae). J Phycol. 2006;42:786-99. 